\title{
REPRODUCTIVE ASPECTS OF THE OCEANIC WHITETIP SHARK, Carcharhinus longimanus (ELASMOBRANCHII: CARCHARHINIDAE), IN THE EQUATORIAL AND SOUTHWESTERN ATLANTIC OCEAN
}

\author{
Mirna Regina dos Santos Tambourgi ${ }^{1, *}$, Fábio H.V. Hazin ${ }^{l}$, Paulo G.V. Oliveira ${ }^{l}$, Rui Coelho ${ }^{2,3}$, \\ George Burgess ${ }^{2}$ and Pollyana C. G. Roque ${ }^{l}$ \\ ${ }^{1}$ Universidade Federal Rural de Pernambuco \\ (Rua Dom Manoel de Medeiros, s/n, 52171-900 Recife, PE, Brasil) \\ ${ }^{2}$ University of Florida - Florida Program for Shark Research, Florida Museum of Natural History \\ (Dickinson Hall, Museum Road, PO Box 117800, Gainesville, FL 32611, USA) \\ ${ }^{3}$ Universidade do Algarve - Centro de Ciências do Mar \\ (Campus de Gambelas, 8000-139 Faro, Portugal) \\ *Corresponding author: mirna.tambourgi@gmail.com
}

\begin{abstract}
A B S T R A C T
The present study sought to study the reproductive biology of the oceanic whitetip shark, Carcharhinus longimanus, in the equatorial and southwestern Atlantic Ocean. A total of 234 specimens were collected as bycatch during pelagic longline fisheries targeting tunas and swordfish, between December 2003 and December 2010. The fishing area was located between latitudes 10N and $35 \mathrm{~S}$ and longitudes $3 \mathrm{E}$ and $40 \mathrm{~W}$. Of the 234 individuals sampled, 118 were females (with sizes ranging from 81 to $227 \mathrm{~cm} \mathrm{TL}$, total length) and 116 males (ranging from 80 to $242 \mathrm{~cm} \mathrm{TL}$ ). The reproductive stages of the females were classed as immature, mature, preovulatory and pregnant, while males were divided into immature, maturing and mature. The size at maturity for females was estimated at $170.0 \mathrm{~cm}$ TL, while that for males was between 170.0 and $190.0 \mathrm{~cm}$ TL. Ovarian fecundity ranged from 1 to 10 follicles and uterine fecundity from 1 to 10 embryos. The reproductive cycle of this species is most likely biennial, with parturition occurring once every two years.
\end{abstract}

\section{RESUMO}

O presente trabalho tem como objetivo estudar a biologia reprodutiva do tubarão galha-branca, Carcharhinus longimanus, para assim ampliar as informações sobre a espécie. A área de estudo compreendeu o Atlântico Sudoeste e Equatorial e foram utilizados 234 espécimes coletados entre dezembro de 2003 e dezembro de 2010. Estes foram obtidos por redes de pesca comercial de atum e peixe-espada e vários tubarões, incluindo o tubarão galha-branca, são capturados nesta pescaria de forma acidental. Esses espinhéis operam no Atlântico Sudoeste e Equatorial entre as latitudes $10 \mathrm{~N}$ e $35 \mathrm{~S}$, e longitudes 3E e 40W. Entre os 234 indivíduos capturados, 118 foram fêmeas $(81$ a $227 \mathrm{~cm}$ de comprimento total, CT) e 116 foram machos ( 80 a $242 \mathrm{~cm} \mathrm{CT).} \mathrm{Os} \mathrm{estados} \mathrm{de} \mathrm{maturação} \mathrm{das} \mathrm{fêmeas}$ foram categorizados como: imaturas, maduras, pré-ovulatórias e grávidas. Os machos foram divididos em: imaturos, em maturação e maduros. O tamanho da primeira maturação para as fêmeas foi estimado em $170 \mathrm{~cm}$ de CT, enquanto que o tamanho de maturação sexual dos machos variou entre 170 e $190 \mathrm{~cm}$ de CT. A fecundidade ovariana oscilou entre um e 10 folículos, enquanto que a fecundidade do útero oscilou entre um e 10 embriões. Os dados indicam que o ciclo reprodutivo é provavelmente bianual, com o nascimento ocorrendo uma vez a cada dois anos.

Descriptors: Reproduction; Maturity stages; Elasmobranch; Viviparity; Size at first maturity; Carcharhinus longimanus.

Descritores: Reprodução; Estágios maturacionais; Elasmobrânquios; Viviparidade; Tamanho de primeira maturação; Carcharhinus longimanus.

\section{INTRODUCTION}

The oceanic whitetip shark, Carcharhinus longimanus (POEY, 1861), is an epipelagic oceanic shark species, occurring in tropical and warm- temperate waters around the world. It has circumtropical distribution, between latitudes $20^{\circ} \mathrm{S}$ and $20^{\circ} \mathrm{N}$, can be found in the Pacific, Indian and Atlantic Oceans, at depths from the surface down to 150m (COMPAGNO, 1984) (Fig. 1). 
Sharks, in general, are particularly vulnerable to overfishing due to their life history characteristics, such as slow growth, late sexual maturity and low fecundity. Thus, shark populations need longer periods of time to recover than do the teleost fishes, as they have been overfished and their populations have declined sharply (CAMHI et al., 2009). According to Hutchings et al. (2012), the comparison of maximum per capita population growth rate or rmax among the vertebrate classes confirms empirically the prediction (HOLDEN, 1973; DULVY et al. 2003; MYERS and WORM, 2005) that the maximum population growth rate, and thus the recovery potential, of sharks, skates, rays and chimaeras is, on average, significantly lower (reflecting increased extinction risk) than that of teleosts. This analysis indicates that this difference in rmax can likely be attributed to the larger body size and older age at maturity characteristic of chondrichthyans. Such biological characteristics, associated with the very high commercial value of their fins, which encourages their catches not only as by-catch but also as targeted species, have led the IUCN (International Union for the Conservation of Nature) to classify the oceanic whitetip shark as vulnerable (BAUM and MYERS, 2004).

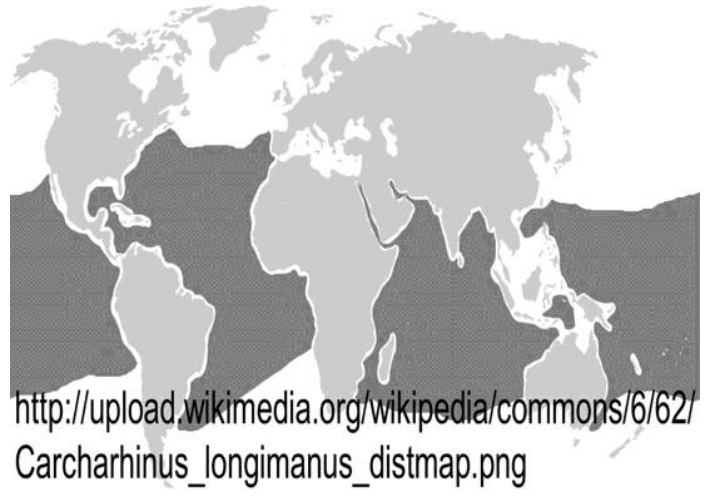

Fig. 1. Map of the geographical distribution of the Oceanic whitetip shark Carcharhinus longimanus

A large number of oceanic whitetip sharks are caught by longline fisheries targeting tunas and swordfish. Most of these sharks are, however, alive when captured (e.g. $75 \%$ in the USA, BEERKIRCHER et al., 2002; 65 to $68 \%$ in Fiji, GILMAN et al., 2008, 66\% in the Atlantic wide Portuguese pelagic longlines, COELHO et al., 2012). Although these figures might indicate that most specimens could survive if they were released alive (CAMHI et al., 2009), the high value of their fins encourages the practice of "finning", despite this practice having been banned in the Atlantic Ocean by the International Commission for the Conservation of
Atlantic Tunas (ICCAT), since 2004. More recently, concerns as to the susceptibility of oceanic whitetip populations to commercial fisheries has led ICCAT to prohibit the catch and retention of this species for commercial purposes in the Atlantic Ocean since 2011.

The information presently available on the oceanic whitetip shark includes reproductive biology (STEVENS, 1984; WHITE, 2007), life history (BACKUS et al., 1956; STRASBURG, 1958; FOURMANOIR, 1961; RANDALL, 1963; GOHAR and MAZHAR, 1964; LINEAWEAVER III and BACKUS, 1970; BASS et al., 1973; GUITART MANDAY, 1975; CADENAT and BLACHE, 1981), distribution (MALCOLM et. al., 1999), population growth rates (BAUM and MYERS, 2004; SMITH et al., 1998; CORTÉS, 2008), movements and migrations (KOHLER et al., 1998), and age and growth studies (SAIKA and YOSHIMURA, 1985; SEKI et al., 1998; LESSA et al., 1999). Although reproductive data have been presented in some of the studies focused on life history, no comprehensive research has ever been carried out on the reproductive biology of the oceanic whitetip shark in the equatorial and South Atlantic Ocean. The objective of this paper was, therefore, to contribute to knowledge on the reproductive biology of this species in the equatorial and southwestern Atlantic Ocean, focusing primarily on estimating the size at maturity, fecundity and its reproductive cycle.

\section{Material and Methods}

In the present study, the reproductive tracts of 234 oceanic whitetip sharks, collected between December 2003 and December 2010, were analyzed. The specimens were caught as by-catch by the Brazilian commercial pelagic longline fishery targeting tunas and swordfish in the equatorial and southwestern Atlantic Ocean. All samples were collected by on board observers, between latitudes $10^{\circ} \mathrm{N}$ and $35^{\circ} \mathrm{S}$ and longitudes $3^{\circ} \mathrm{E}$ and $40^{\circ} \mathrm{W}$ (Fig. 2).

All the specimens were identified and measured for total length (TL) immediately after boarding, and for analysis these measurements were grouped into classes of $10 \mathrm{~cm}$ TL, by sex. In the case of males, the outer clasper length and its degree of calcification were also recorded. After evisceration, the reproductive tracts of all the specimens were collected and preserved frozen. Once in the laboratory, the weight and width of the testes were measured.

For females, the width and weight of the ovary (only one ovary is functional in this species) were recorded and the number of ovarian follicles counted, the diameter of the largest one being measured. The width of the uteri was also recorded and the number, sex and total length of embryos, whenever present, were recorded. 

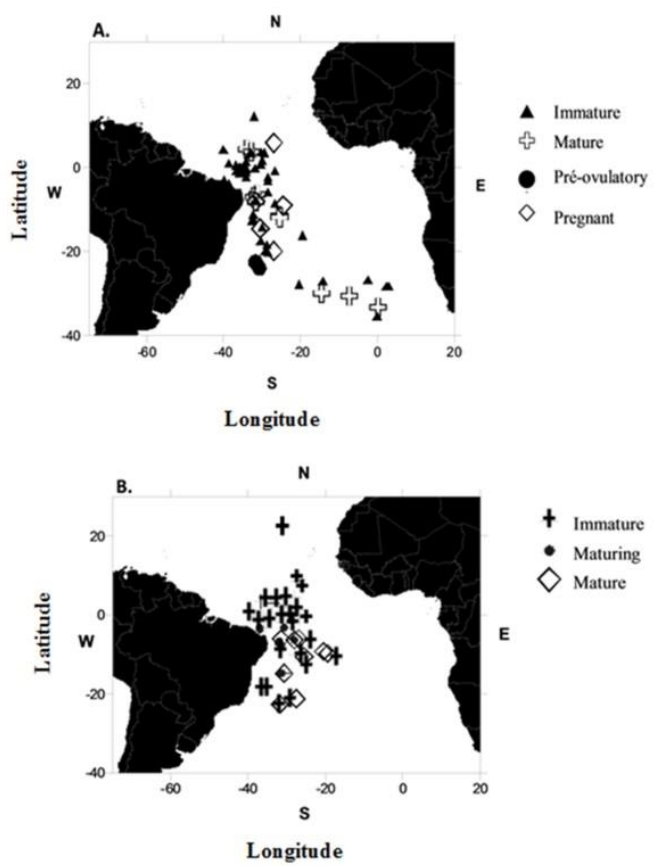

Fig. 2. Geographical location of the specimens caught for this study. Map 1A represent females and map 1B represents males.

The maturity ogives for determining the size at first maturity were not used, due to the low number of mature individuals in relation to the total number of individuals in the sample. We then decided to analyze the first maturity of females and males using the weight of the ovaries, and testes and clasper, respectively, and by macroscopic observation of the reproductive tract.

The size distribution of the two sexes was plotted, and a Kolmogorov-Smirnov test (considering a significance level of 95\%) was applied to compare the frequency of distributions between the sexes.

Carcharhinus longimanus is a viviparous placental species, and therefore, the specimens were categorized using a scale of sexual maturity for this type of reproductive development. Female reproductive stages were categorized as: immature, mature, pre-ovulatory and pregnant, depending on the development of the ovary, uteri and oviducal glands. Specifically, immature females were characterized by having filiform uteri and undeveloped ovaries, with small barely visible whitish and undistinguishable ovarian follicles. The mature females had large ovaries with enlarged yolk follicles of different sizes, fully developed uteri and oviducal glands, with some vitellogenic follicles in the ovary, although they were not yet near ovulation. The pre-ovulatory females had developed ovaries, with large and yellow vitellogenic follicles ready to be ovulated. The oviducal glands of females in this stage were large and wide, indicating that ovulation was probably close. Finally, the pregnant females had large and developed uteri, containing embryos.

Males were classed in three maturity stages: juvenile, maturing and mature. Immature specimens had small and flexible (not calcified) claspers, shorter than the pelvic fins, filliform ampullae ductus deferens, small testes and thread-like sperm ducts. The maturing specimens were characterized by virtue of their enlarged testes, claspers still flexible though as long or longer than the pelvic fin tips, and sperm ducts developing and beginning to coil (meander) (ICES, 2010). The mature specimens were characterized by their large, rigid and calcified claspers, longer than the pelvic fins, and greatly enlarged testes and epididymides. In these specimens, the sperm ducts were tightly coiled and filled with sperm (ICES, 2010).

The ovarian fecundity was estimated by counting the number of maturing oocytes in mature and pre-ovulatory females, while the uterine fecundity was estimated by counting the embryos in the uteri of pregnant specimens. The average lengths of the embryos by sex were calculated by the arithmetic mean of the sum of the lengths of the embryos/number of individuals by sex. The embryos in each of the uteri (left and right side) were counted and measured separately and then compared with a nonparametric Mann-Whitney test, considering a significance level of $95 \%$. The sex ratios were calculated, and the differences between the observed and the expected $50 \%$ ratios were tested with a $\mathrm{X}^{2}$ test, with a significance level of $95 \%$.

\section{RESUlts}

It may be seen from Figure 2 that the individuals were caught between $10^{\circ} \mathrm{N}$ and $35^{\circ} \mathrm{S}$ latitude and $3^{\circ} \mathrm{E}$ and $40^{\circ} \mathrm{W}$ longitude. They were well distributed throughout the study area, and it may be noted that the immature specimens, both female and male, were concentrated in equatorial latitudes, while specimens in other maturational stages were more widespread .

Of the 234 individuals sampled, 118 (50.4\%) were females and 116 (49.6\%) males, resulting in a sex ratio close to $1: 1$ (Table 1) with no significant difference $\left(X^{2}=0.02<X^{2}{ }_{0.05}=3.84\right)$. In some months differences were observed in the sex ratios, but none of them was significant.

There were no significant differences between TL of males and females (KolmogorovSmirnov, $p>0.05$ ). The total length of the specimens examined ranged between 80 and $242 \mathrm{~cm}$ TL for males, and 81 and $227 \mathrm{~cm} \mathrm{TL}$ for females, with both sexes showing a higher frequency of occurrence between 100 and $120 \mathrm{~cm}$ TL (Fig. 3). 
Table 1. Monthly and total sex ratio of the oceanic whitetip shark, Carcharhinus longimanus, caught in the equatorial and southwestern Atlantic Ocean, from 2003 to 2010.

\begin{tabular}{cccccc}
\hline & Males & Females & Total & Males (\%) & Females (\%) \\
\hline January & 15 & 12 & 27 & 55.6 & 44.4 \\
February & 10 & 13 & 23 & 43.5 & 56.5 \\
March & 11 & 11 & 22 & 50.0 & 50.0 \\
April & 4 & 10 & 14 & 28.6 & 71.4 \\
May & 6 & 6 & 12 & 50.0 & 50.0 \\
June & 7 & 9 & 16 & 43.8 & 56.3 \\
July & 5 & 8 & 13 & 38.5 & 61.5 \\
August & 5 & 3 & 8 & 62.5 & 37.5 \\
September & 10 & 14 & 24 & 41.7 & 58.3 \\
October & 14 & 7 & 21 & 66.7 & 33.3 \\
November & 15 & 8 & 23 & 65.2 & 34.8 \\
December & 14 & 17 & 31 & 45.2 & 54.8 \\
Total & 116 & 118 & 234 & 49.6 & 50.4 \\
\hline
\end{tabular}

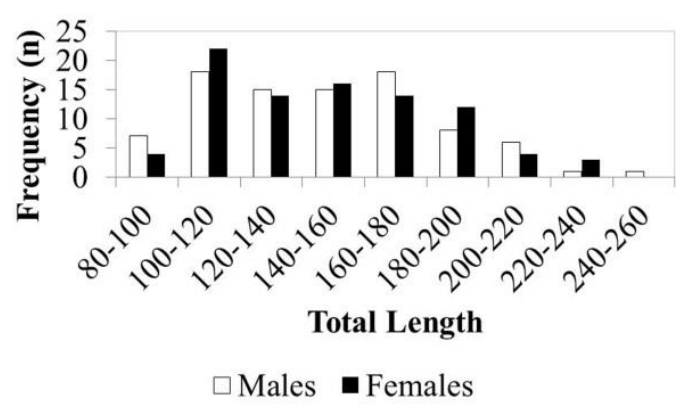

Fig. 3. Length-frequency distribution of male and female oceanic whitetip shark, Carcharhinus longimanus, caught in the equatorial and southwestern Atlantic Ocean.

Of the 118 females, $95 \quad(80.5 \%)$ were immature (90 to $170 \mathrm{~cm} \mathrm{TL),} 15$ were mature (13\%) (165 to $223 \mathrm{~cm} \mathrm{TL),} \mathrm{two} \mathrm{were} \mathrm{pre-ovulatory}(1.7 \%)$ (181 and $187 \mathrm{~cm} \mathrm{TL})$ and six were pregnant (5\%) (169 to $227 \mathrm{~cm} \mathrm{TL}$ ) (Table 2). The relationships between the width of the oviducal glands (Fig. 4), the width of the uteri (Fig. 5) and the weight of the ovaries (Fig. 6 ) in the light of the total length of the females examined suggest that sexual maturity is attained at around $170 \mathrm{~cm}$ TL.

The ovarian fecundity ranged between 1 and 10 follicles. The largest ovarian follicle was $4.6 \mathrm{~cm}$ in diameter in a pre-ovulatory female with $187 \mathrm{~cm} \mathrm{TL}$ (Table 2). The uterine fecundity ranged from 1 to 10 embryos, with an average of 6.0 embryos per female, 2.9 embryos in the right uterus and 3.1 in the left uterus, although no significant differences in the number of embryos were found between the two uteri (Mann-Whitney test: $\mathrm{p}$-value $=0.05, \alpha=5 \%$ ).

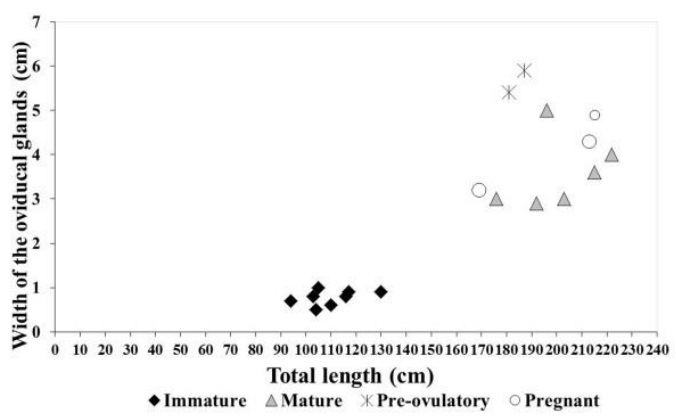

Fig. 4. Relationship between total length and the width of the oviducal glands of female oceanic whitetip shark, Carcharhinus longimanus, in the equatorial and southwestern Atlantic Ocean.

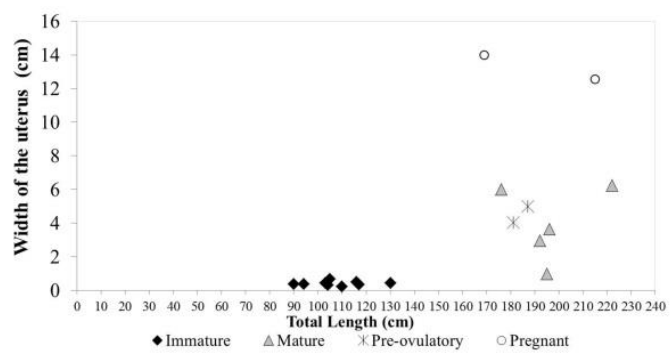

Fig. 5. Relationship between total length and the width of the uteri of female oceanic whitetip shark, Carcharhinus longimanus, in the equatorial and southwestern Atlantic Ocean.

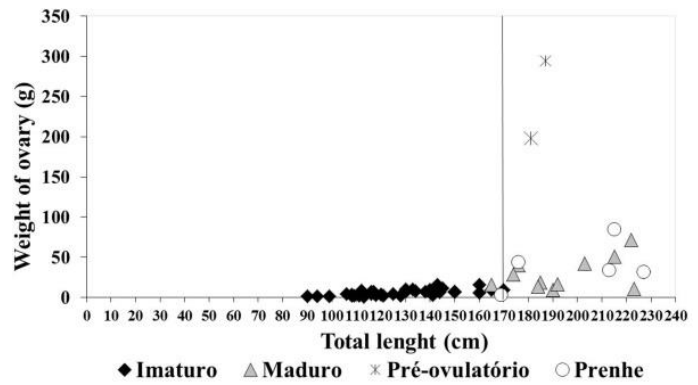

Fig. 6. Relationship between total length and ovary weight for female oceanic whitetip shark, Carcharhinus longimanus, caught in the equatorial and southwestern Atlantic Ocean. (The vertical bar represents the size at first maturity of females, estimated at $170 \mathrm{~cm}$ ). 
Table 2. Characteristics of the embryos found in pregnant females of oceanic whitetip shark, Carcharhinus longimanus, in the equatorial and southwestern Atlantic Ocean.

\begin{tabular}{|c|c|c|c|c|c|c|c|c|c|}
\hline \multirow[t]{2}{*}{$\begin{array}{l}\text { Month/Year } \\
\text { of capture }\end{array}$} & \multicolumn{3}{|c|}{$\begin{array}{c}\text { Mean TL of embryos } \\
\text { by sex }(\mathrm{cm})\end{array}$} & \multicolumn{2}{|c|}{$\begin{array}{c}\text { Number } \\
\text { of } \\
\text { embryos }\end{array}$} & & \multirow[t]{2}{*}{ Total } & \multirow[t]{2}{*}{$\begin{array}{l}\text { Sex } \\
\text { ratio }\end{array}$} & \multirow[t]{2}{*}{$\begin{array}{c}\text { TL of } \\
\text { mother } \\
\text { (cm) }\end{array}$} \\
\hline & $\mathbf{F}$ & $\mathbf{M}$ & $T$ & M & $\mathbf{F}$ & $\mathbf{U}$ & & & \\
\hline Ap/09 & 0 & 0 & 2.9 & 0 & 0 & 4 & 4 & 0 & 176 \\
\hline May/09 & 23,6 & 23,6 & 23.61 & 5 & 4 & 0 & 9 & $1 \mathrm{M}: 1 \mathrm{~F}$ & 189 \\
\hline Jul/04 & 9,8 & 0 & 9.8 & 0 & 8 & 0 & 8 & $8 \mathrm{~F}$ & 215 \\
\hline Sept/07 & 32,1 & 31,6 & 31.85 & 5 & 5 & 0 & 10 & $1 \mathrm{M}: 1 \mathrm{~F}$ & 213 \\
\hline Nov/07 & 52 & 0 & 52 & 0 & 1 & 0 & 1 & $1 \mathrm{~F}$ & 227 \\
\hline Dec/08 & 0 & 0 & 6.5 & 0 & 0 & 4 & 4 & 0 & 169 \\
\hline Total & 6,52 & 5,52 & $2.9-52$ & 10 & 18 & 8 & 36 & $1 \mathrm{M}: 1.8 \mathrm{~F}$ & $169-227$ \\
\hline
\end{tabular}

$\mathrm{T}=$ Total $\mathrm{M}=$ Male $; \mathrm{F}=$ Female, $\mathrm{U}=$ Unidentified sex

Overall, a total of 36 embryos from 6 females were observed. The mean total length of the embryos ranged from $2.9 \mathrm{~cm}$, in a female caught in April 2009, to a maximum of $52 \mathrm{~cm}$ from a female caught in November 2007 (Table 2). The sex was identified in all but eight of the embryos. Of the 28 embryos in which the sex was determined, 10 were males $(35.7 \%)$ and 18 were females $(64.3 \%)$, representing a male:female sex ratio of $1: 1.8$ (Table 2).

We found no significant differences in the sizes of embryos by sex, even though the females were slightly longer than the males (Table 2).

Only one pregnant female, with $176 \mathrm{~cm}$ TL and 4 embryos with a mean total length of $2.9 \mathrm{~cm}$, presented a vitellogenic ovarian follicle measuring 3.7 $\mathrm{cm}$. None of the other pregnant females examined presented any vitellogenic activity in its ovary. However, it was not possible to determine the existence of a resting period in females in this study.

Immature females were caught throughout the year, whereas mature and pregnant females were together present only in the second half of the year, except for a total of 3 mature and two pregnant specimens caught in May and April. The two preovulatory females were both caught in January (Fig. 7).

Of the 116 males examined, 84 were immature $(72.4 \%)(72$ to $160 \mathrm{~cm} \mathrm{TL}), 12$ were maturing (10.3\%) (170 to $196 \mathrm{~cm} \mathrm{TL})$, and 20 were mature $(17.3 \%$ ) (160 to $242 \mathrm{~cm}$ TL) (Table 3 ).

The relationships between testes weight and total length (Fig. 8) and clasper length and total length
(Fig. 9) and especially the macroscopic observation of the reproductive tract indicated that sexual maturity in males was attained in the interval between 170 and $190 \mathrm{~cm}$ TL.

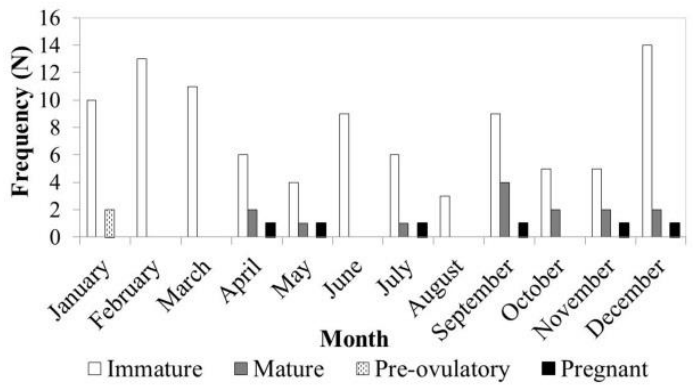

Fig. 7. Monthly distribution of maturity stages of female oceanic whitetip shark, Carcharhinus longimanus, caught in the equatorial and southwestern Atlantic Ocean, from 2003 to 2010.

Table 3. General characteristics of maturation stages of male oceanic white tip sharks, Carcharhinus longimanus, caught in the equatorial and southwestern Atlantic Ocean. WIT = Testes width; WET $=$ Weight of testicules; LC $=$ Length of clasper; $\mathrm{TL}=$ Total Length; $\mathrm{N}=$ Number of specimens; $\%=$ percentage.

\begin{tabular}{cccc}
\hline Characteristios & Immature & Maturing & Mature \\
\hline WIT $(\mathrm{cm})$ & $0.7-2.9$ & $1.5-7.9$ & $1.1-4.6$ \\
WET $(\mathbf{g})$ & $0.4-17.8$ & $6.4-37$ & $9.4-125$ \\
LC (cm) & $2.8-7.0$ &. & $15-21$ \\
$\mathbf{T}(\mathbf{c m})$ & $72-169$ & $170-196$ & $160-242$ \\
$\mathbf{X}$ & 84 & 12 & 20 \\
$\%$ & 72.41 & 10.34 & 17.3 \\
\hline
\end{tabular}

* No individual clasper length was measured for maturing specimes

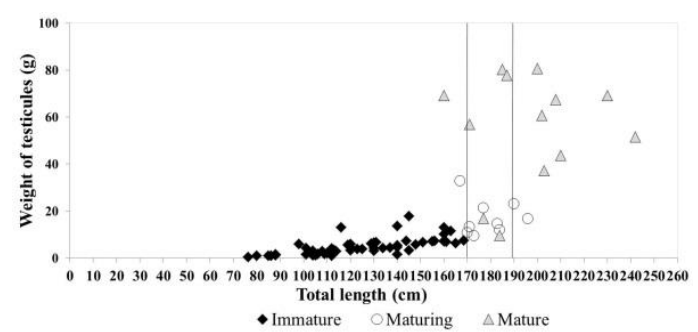

Fig. 8. Relationship between testicules weight and total length for male oceanic whitetip shark, Carcharhinus longimanus, caught in the equatorial and southwestern Atlantic Ocean (vertical bars represent the range of size in which males attain their first maturity, i.e. $170 \mathrm{~cm}$ to 190 $\mathrm{cm})$. 


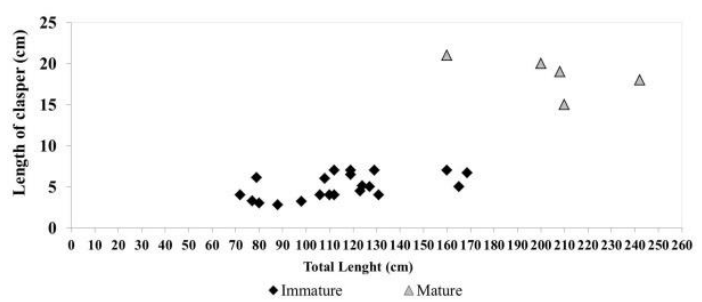

Fig. 9. Relationship between the length of the clasper and total length for male oceanic whitetip shark, Carcharhinus longimanus, caught in the equatorial and southwestern Atlantic Ocean.

\section{Discussion}

The size at first maturity for females, estimated at around $170 \mathrm{~cm} \mathrm{TL}$, is on the lower limit of the range estimated by Bass et al. (1973), who suggested a size at first maturity for the species of between 170 and $180 \mathrm{~cm}$. Other authors have, however, found slightly larger sizes at first maturity, such as from 175 to $189 \mathrm{~cm}$ (SEKI et al., 1998), from 180 to $190 \mathrm{~cm}$ (LESSA et al., 1999), and from 180 to $200 \mathrm{~cm}$ (COMPAGNO, 1984). The presence of a pregnant female with a total length of $169 \mathrm{~cm}$ in the present sample, however, does confirm that maturity may be reached at a size even slightly lower than 170 $\mathrm{cm}$. The discrepancy in the sizes of maturity between studies may be due to the use of different criteria in distinguishing between the maturity stages and, in the present study, to the low number of mature individuals observed.

White (2007), in a study carried out in Indonesia, suggested a size at maturity for males between 190 and $240 \mathrm{~cm}$ TL. In this study, the sexual maturity of males seemed to be occurring between 170 and $190 \mathrm{~cm} \mathrm{TL}$, thus within a smaller size range than that suggested by the author quoted.

The amplitude of uterine fecundity for both uteri ( 1 to 10 embryos, with an average of 6 ), in turn, was also a little lower than those found by Seki et al. (1998), for the North and South Pacific Oceans (1 to 14 and 1 to 12 embryos, respectively). Reports of abnormally small litters, such as 1 or 2 in Carcharhinus species and 4 in the blue shark, may be due to counting young that remained after part of the litter had been aborted, as often happens when pregnant elasmobranchs are boated or handled (BONFIL et al., 1993). Such a characteristic of Carcharhinus species may explain the relatively low uterine fecundity (in some cases) found in the present study.

The oviducal glands of elasmobranchs are involved in the storage of spermatozoa and the production of an egg-laying cement. The elasmobranchs that develop sperm storage capabilities and the styles of their employment are quite varied. As in other animals which internally inseminate numerous ova from a single copulation, sperm must be retained for at least the duration of ovulation to permit insemination. This necessitates the development of a seminal receptacle in close enough proximity to the passing ovum to permit insemination but far enough out of the main stream of egg movement to ensure retention of most of the sperm. As selective pressure over time has favored sperm retention in the oviducal gland, sperm storage was a logical consequence. Its development probably facilitated the adoption of a nomadic lifestyle by many pelagic species, such as the tiger and scalloped hammerhead, as well as the delayed fertilization in the far-ranging blue shark (PRATT Jr., 1992).

The fact that pregnant females showed no vitellogenic activity in the ovary, except for one specimen, suggests that they are not ready for a new ovulation and pregnancy soon after giving birth, as was also reported by Seki et al. (1998) for the same species. The only pregnant female that had a vitellogenic follicle was in early gestation, suggesting that either the ovulation process was not yet complete or that the remaining oocytes in the ovary were probably being reabsorbed.

Although the pregnant females examined in this study were caught in different years, making it rather difficult to compare their embryonic development, the mean total length of their embryos seemed to increase throughout the year, from $2.9 \mathrm{~cm}$ in April, to a maximum of $52.0 \mathrm{~cm}$ in November, decreasing, then, to $6.5 \mathrm{~cm}$ in December. Amorim et al. (1998), working with specimens caught in more southern latitudes along the Brazilian coast, found full term embryos (63.0 to $69.7 \mathrm{~cm} \mathrm{TL}$ ) between July and November (winter/spring), which probably indicates a relatively extended parturition period for this species, as proposed by Seki et al (1998) for the Pacific Ocean. On the South African coast, Bass et al. (1973) found full term embryos between September and October (winter/spring). Reports of fully formed embryos of Carcharhinus longimanus give a range of 55 to $77 \mathrm{~cm}$, with most estimates falling within the 60 to $70 \mathrm{~cm}$ range (BONFIL et al., 2008). Seki et al. (1998) examined embryos as large as $75 \mathrm{~cm}$, and free swimmers as small as $66 \mathrm{~cm}$.

These data suggest that parturition of the oceanic whitetip shark in the Southwest Atlantic Ocean is probably concentrated in the second half of the year, with ovulation taking place at the end/beginning of the year. This information, together with the fact that pregnant females do not have an ovarian development concomitant with embryonic growth, suggests a biennial reproductive cycle, with 
gestation and ovarian development occurring in alternate years. In the Northwestern Atlantic, the gestation period is about 12 months (BONFIL et al., 2008) agreeing with that presented in the present study.

The oceanic whitetip shark, as most other pelagic shark species, seems to have a life history with parameters that make their populations particularly vulnerable to overfishing. This shark species clearly has a relatively low fecundity, aggravated by a likely biennial reproductive cycle, with females giving birth only once every two years. The present results reinforce the need to adopt conservation measures capable of reducing the mortality of the oceanic whitetip shark in the tuna longline fishery, probably the primary source of fishing mortality for this species in oceanic waters.

\section{ACKNOWLEDGMENTS}

The present work received financial support from the "Secretaria Especial de Aquicultura e Pesca" of the Brazilian Government. Thanks are due to the crews of the Brazilian commercial vessels concerned and the fishery observers, for collecting the samples. Rui Coelho was supported by a grant from FCT (Ref: BPD 40523/2007) co-funded by "POCI2010 Programa Operacional Ciência e Inovação 2010" and "FSE Fundo Social Europeu".

\section{REFERENCES}

AMORIM, A. F.; ARFELLI, C. A.; FAGUNDES, L. Pelagic elasmobranches caught by longliners off southern Brazil during 1974-97: an overview. Mar. Freshwater Res., v. 49, n. 7, p. 621-632, 1998.

BACKUS, R. H.; SPRINGER, S.; ARNOLD Jr., E. L. A contribution to the natural history of the white-tip shark: Pterolamiops longimanus (Poey). Deep-Sea Res., v. 3, n. 3, p. 178-188, 1956.

BASS, A. J.; D'AUBREY, J. D.; KISTNSAMY, N. Sharks of the east coast of Southern Africa. I. Genus Carcharhinus (Carcharhinidae). Durban: Oceanographic Research Institute, 1973. 168 p. (South Africa Association for Marine Biological Research Oceanographic Research Institute, Investigational Report; n. 33).

BAUM, J. K.; MYERS, R. A. Shifting baselines and the decline of pelagic sharks in the Gulf of Mexico. Ecol. Lett., v. 7, p. 135-145, 2004.

BEERKIRCHER, L. R.; CORTÉS, E.; SHIVJI, M. Characteristics of shark bycatch observed on pelagic longlines off the Southeastern United States, 1992-2000. Mar. Fish. Rev., v. 64, n. 4, p. 40-49, 2002

BONFIL, R.; CLARKE, S.; NAKANO, H. The biology and ecology of the Oceanic whitetip shark, Carcharhhinus longimanus. In: CAMHI, M. D.; PIKITCH, E. K.; BABCOCK, E. A. (Eds.). Sharks of the open ocean: biology, fisheries and conservation. Oxford: Blackwell
Science, 2008. cap. 11, p. 128-139. (Fish and aquatic resources series; 13) [International Pelagic Shark Workshop, 2000, Pacific Grove, Calif.].

BONFIL, R.; MENA, R.; ANDA, D. Biological parameters of commercially exploited silky sharks, Carcharhinus falciformes, from the Campeche Bank, Mexico. In: BRANSTETTER, S. (Ed.). Conservation biology of elasmobranchs. Silver Spring: NOAA/NMFS, 1993. p. 73-86. (NOAA Technical Report NMFS; 115).

CADENAT, J.; BLACHE, J. Requins de Méditerranée et d'Atlantique: plus particulièrement de la côte occidentale d'Afrique. Paris: Editions de l'Office de la Recherche Scientifique et Technique Outre-mer, 1981. 330 p. (Faune Tropicale; 21).

CAMHI, M. D.; VALENTI, S. V.; FORDHAM, S. V.; FOWLER, S. L.; GIBSON, C. (Eds.). The conservation status of pelagic sharks and rays. Newbury: IUCN Species Survival Commission's Shark Specialist Group, 2009. 78 p. [Report of the IUCN Shark Specialist Group Pelagic Shark Red List Workshop Tubney House, University of Oxford, UK, 19-23 February 2007].

COELHO, R.; FERNANDEZ-CARVALHO, J.; LINO, P. G.; SANTOS, M. N. An overview of the hooking mortality of elasmobranchs caught in a swordfish pelagic longline fishery in the Atlantic Ocean. Aquat. Living Resour., v. 25, p. 311-319, 2012.

COMPAGNO, L. J. V. Sharks of the world: an annotated and illustrated catalogue of shark species known to date. Rome: Food and Agriculture Organization of the United Nations, 1984. v.4, p. 251-655. (FAO fisheries synopsis; n. 125) [Part. 2: Carcharhiniformes].

CORTÉS, E. Comparative life history and demography of pelagic sharks. In: CAMHI, M. D.; PIKITCH, E. K.; BABCOCK, E. A. (Eds.). Sharks of the open ocean: biology, fisheries and conservation. Oxford: Blackwell Science, 2008. cap. 11, p. 309-322. (Fish and aquatic resources series; 13) [International Pelagic Shark Workshop, 2000, Pacific Grove, Calif.].

DULVY, N. K.; SADOVY, Y.; REYNOLDS, J. D. Extinction vulnerability in marine populations. Fish Fish., v. 4, n. 1, p. 25-64, 2003.

FOURMANOIR, P. Requins de la côte ouest de Madagascar. [S.1.: s.n.], 1961. p. 1-81. (Memoires de 1'Institut Scientifique de Madagascar, Serie F. Océanographie, v. 4).

GILMAN, E.; CLARKE, S.; BROTHERS, N.; ALFAROSHIGUETO, J.; MANDELMAN, J.; MANGEL, J.; PETERSEN, S.; PIOVANO, S.; THOMSON, N.; DALZELL, P.; DONOSO, M.; GOREN, M.; WERNER, T. Shark interactions in pelagic longline fisheries. Mar. Policy, v. 32, n. 1, p. 1$18,2008$.

GOHAR, H. A. F.; MAZHAR, F. M. The elasmobranches of the North-Western Red Sea: the internal anatomy of Selachii from the North Western Red Sea: keeping elasmobranches in vivaria. [S.1.]: Cairo University Press, 1964. p. 3-143. (Publitions of the Marine Biological Station, Ghardaqa; v. 13).

GUITART MANDAY, D. Las pesquerias pelágicooceanicas de corto radio de acción en la region noroccidental de Cuba. Havana: Instituto de Oceanologia, Academia de Ciencias de Cuba, 1975. 26 p. (Serie Oceanologia; 31). 
HOLDEN, M. J. Are long-term sustainable fisheries for elasmobranchs possible? In: PARISH, B. B. (Ed.). Fish stocks and recruitment: Proceedings of a Symposium Held in Aarhus, 7-10 July, 1970. [S.1.]: Conseil International pour L'Exploration de la Mer, 1973. p. 360-367. (Rapports et Proces-Verbaux des Reunions Conseil International pour l'Exploration de la Mer; v. 164).

HUTCHINGS, J. A.; MYERS, R. A.; GARCIA, V. B.; LUCIFORA, L. O.; KUPARINEN, A. Life-history correlates of extinction and recovery potential. Ecol. Appl., v. 22, n. 4, p. 1061-1067, 2012.

ICES. Report of the Workshop on Sexual Maturity Staging of Elasmobranches (WKMSEL): 11-15 October 2010, Valetta, Malta. Copenhagen: International Council for the Exploration of the Sea, 2010. 132 p. (WKMSEL Report 2010, Ices Advisory Committee, ICES CM 2010/ACOM; 48).

KOHLER, N. E.; CASEY, J. G.; TURNER, P. A. NMFS Cooperative shark tagging program, 1962-93: an atlas of shark tag and capture data. Mar. Fish. Rev., v. 60, n. 2, p. 1-87, 1998.

LESSA, R.; SANTANA, F. M.; PAGLERANI, R. Age, growth and stock structure of the oceanic whitetip shark, Carcharhinus longimanus, from the southwestern equatorial Atlantic. Fish. Res., v. 42, n. 1/2, p. 21-30, 1999.

LINEAWEAVER III, T. H.; BACKUS, R. H. The natural history of sharks. Philadelphia: J.B. Lippencott, 1970. $256 \mathrm{p}$.

Malcolm P. Francis, Worthington, Craig J., Saul Peter; Clements, Kendall D. 1999. New and rare tropical and subtropical fishes from northern New Zealand', New Zealand Journal of Mar and Freshw Res, 33: 4, 571 586.

MYERS, R. A.; WORM, B. Extinction, survival or recovery of large predatory fishes. Philos. Trans. R. Soc., B: Biol. Sci., v. 360, n. 1453, p. 13-20, 2005.
PRATT Jr., H. L. The storage of spermetazoa in the oviducal glands of western North Atlantic sharks. Environ. Biol. Fishes, v. 38, n. 1/3, p. 139-149, 1992.

RANDALL, J.E. Dangerous sharks of the Western Atlantic. In: GILBERT, P. W.; GARRICK, J. A. F.; SCHULTZ, L. P. (Eds.). Sharks and survival. Boston: C. D. Heath and Co., 1963. p. 339-362.

SAIKA, S. and YOSHIMURA, H. Oceanic whitetip shark (Carcharhinus longimanus) in the western Pacific. Report of the Japanese Group for Elasmobranch Studies, v. 20, p. 11-21, 1985.

SEKI, T.; TANIUCHI, T.; NAKANO, H.; SHIMIZU, M. Age, growth and reproduction of the Oceanic Whitetip Shark from the Pacific Ocean. Fish. Sci., v. 64, n. 1, p. 14-20, 1998.

SMITH, S. E.; AU, D. W.; SHOW, C. Intrinsic rebound potentials of 26 species of Pacific sharks. Mar. Freshwater Res., v. 49, p. 663-678, 1998.

STEVENS, J. D. Biological observations on sharks caught by sport fishermen off New South Wales. Aust. J. Mar. Freshwater Res., v. 35, p. 573-590, 1984.

STRASBURG, D. W. Distribution, abundance and habits of pelagic sharks in the Central Pacific Ocean. Washington: United States Government Printing Office, 1958. p. 335-361, (Fishery Bulletin; 138. Fishery Bulletin of the Fish and Wildlife Service; v.58).

WHITE, W. T. Catch composition and reproductive biology of whaler sharks (Carcharhiniformes: Carcharhinidae) caught by fisheries in Indonesia. J. Fish Biol., v. 71, p. 1512-1540, 2007.

(Manuscript received 18 February 2013; revised 28 April 2013; accepted 16 May 2013) 